\title{
Challenges and Opportunities
}

\author{
Linda H. Geiser, Toral Patel-Weynand, Anne S. Marsh, \\ Korena Mafune, and Daniel J. Vogt
}

\section{Introduction}

There is an inseparable connection between the health of soils and the well-being of people. Disturbances-changing climate and environment, invasive species, increasing wildfire severity and frequency, land management practices, and land use changes-are affecting soil health in complex ways that are only partially understood. This assessment provides a baseline for soil health by synthesizing the most recent research on the properties and processes characterizing forest, rangeland, wetland, and urban soils at regional and national levels. It also summarizes the current state of knowledge about the effects of historical and ongoing disturbances. Finally, it highlights the technologies, networks, and outreach programs central to future research on, and monitoring and management of, the nation's soils. The state of the knowledge indicates that adverse changes to soil properties could, in the long term, undermine the primary ecosystem services provided by soils: abundant water, food, and fiber and moderation of climate warming. Research that can further explain the underlying principles of soil science and the effects of disturbances is needed to inform policies and management practices to optimize soil health on a broad scale and support human health and welfare through the twentyfirst century.

L. H. Geiser $(\varangle) \cdot$ T. Patel-Weynand

Washington Office, U.S. Department of Agriculture, Forest

Service, Washington, DC, USA

e-mail: Linda.geiser@usda.gov

A. S. Marsh

U.S. Department of Agriculture, Forest Service, Bioclimatology and Climate Change Research, Washington, DC, USA

K. Mafune

School of Environmental and Forest Science, University of Washington, Seattle, WA, USA

D. J. Vogt

School of Environmental and Forest Science, University of Washington, Seattle, WA, USA
In this chapter, we identify key challenges and opportunities for soils research and management grouped by overarching themes: (1) understanding basic soil properties and processes; (2) understanding disturbance effects; (3) monitoring, modeling, mapping, and data-sharing; (4) training the next generation of scientists; and (5) managing soils. Each theme is introduced with a short recapitulation of its significance and associated issues. Please see the individual chapters and appendixes of this report for a fuller discussion of topical and regional issues, research findings, and information gaps.

A distinct advantage of this particular time in history is that the scientific understanding of soils, the quantity of soils data, and the consistency, organization, and accessibility of these data have never been greater or of higher quality. Numerous federally funded efforts; long-term monitoring networks (Appendix B) and studies; collaborations across multiple agency, state, and private research institutions, together with contributions by nongovernmental organizations and private enterprise; and advances in chemical, physical, and computational techniques are enabling researchers to gather and interpret immense quantities of data. From detailed genomic descriptions of the microbial diversity found in a gram of soil to satellite-mounted instruments allowing the remote assessment of soil moisture across vast swaths of the planet, new tools are yielding information at scales and in quantities that were previously unthinkable. Assessments of these new data along with those from traditional approaches and on-site measurements are informing science-based management recommendations that are setting the stage for sitespecific tailoring of soil management practices (Chap. 9). These advances in technology, communication, monitoring, and networking are the prime resources and create the opportunities for addressing the research challenges critical to solving the daunting tasks of growing enough food and sustaining the nation's soil-driven ecosystem services into the future.

It is no coincidence that the words "earth" and "soil" are often used interchangeably in ordinary conversation. It is a crucial concept that a narrow range of conditions for both pro- 
vides the foundation for life on Earth. Even with modern tools, technologies, and available science and information, there is still so much to learn about the astounding diversity of life in a healthy soil, and there are still so many unanswered questions (Appendix C) about interactive properties and processes in soils. The answers to these questions will be key in sustaining soil health. On the other hand, the terms "dirt" and "soil" are also used interchangeably. The way that resources are verbalized shapes conceptualizations and, down the line, options and actions. If a long-term goal is to optimize the health, sustainability, and productivity of soils, then a simultaneous challenge and opportunity is to reiteratively frame research questions, research and monitoring activities, communications, and management practices in a way that reflects a respect for, and accurate understanding of, the complex interactions among soil physical, chemical, and biological properties, natural and human disturbances, and human health and welfare.

Below are some actions and best management practices that can be undertaken to address challenges and opportunities to further soil science and soil sustainability. They are not intended as recommendations or to be prescriptive in any way, but are intended to encourage thinking and action to enhance soil conditions and their management.

\section{Understanding Basic Soil Properties and Processes}

\section{Significance}

Information about fundamental soil properties and processes is indispensable to the development of science-based policies and practices. Well-designed policies and practices can sustain soil, water, and air resources; protect soil fertility, water infiltration, and water holding capacity; reduce and prevent erosion and sedimentation; and protect the organic matter, soil moisture, and soil invertebrates and microorganisms essential to soil chemical and physical processes.

\section{Challenges and Opportunities}

- Understanding soil organic matter accumulation and loss (Chap. 2). Globally, soil $\mathrm{C}$ is the largest terrestrial pool. Soils store about $2.3 \times 10^{15} \mathrm{~kg}$ or 2300 petagrams $(\mathrm{Pg})$ organic $\mathrm{C}$ in the top $2 \mathrm{~m}$ and about $500 \mathrm{Pg}$ more below that, representing greater than half the global terrestrial $\mathrm{C}$ sink. About $75 \%$ of that total is in forest soils, $12 \%$ in grassland and shrubland soils, and $10 \%$ in tundra soils (Jackson et al. 2017). A critical research frontier is the study of soil organic matter accumulation, its loss from soils, and its complex interactions with soil structure (which can physically protect molecules from decay) and with minerals (many of which are oxygen-sensitive and whose availability for uptake and oxidation state may change with changing climate). This is particularly important for addressing soil pollution. Additional research challenges are understanding (1) how $\mathrm{C}$ dynamics differ between organic and mineral horizons, (2) how to reduce uncertainties in estimations of soil C, and (3) the contribution of deep roots to organic matter inputs below $30 \mathrm{~cm}$.

- Understanding soil water and hydrologic processes (Chap. 3). Despite their importance, many soil water processes are still incompletely understood-even in relatively unperturbed ecosystems. Key research challenges include improving hydrologic models to predict soil water dynamics at watershed scales and accurately quantifying water storage capacity and water dynamics at a variety of scales. Because infiltration is important to soil moisture holding capacity, it is necessary to understand the isolated effect of soil water repellency on infiltration and runoff and how those rates can be quantified at the watershed scale given the large temporal and spatial variability of soil water repellency. Related questions include how soil moisture changes with depth and how moisture profiles vary among soils. Understanding soil water can inform soil restoration and basic management practices and mitigation options for drought, flooding, and sea-level rise.

- Understanding soil fertility and nutrient cycling processes (Chap. 4). Soil nutrients are essential for plant growth. Because nutrient availability is a key driver of net primary productivity, one of the biggest research challenges of the near future will be to refine conceptual models and techniques for quantifying mineral weathering, a major source of soil nutrients. Understanding local and regional soil differences that affect retention of base cations in soil can help to customize mitigation prescriptions for disturbed soils.

- Understanding the identity and roles of soil biota (Chap. 5). Soil organisms account for about 25-30\% of all species on Earth (Decaëns et al. 2006) and differ vastly in size, mobility, and ecological function. Collectively they flourish in a multitude of soil physical and chemical habitats-yet only a fraction of soil-dependent species have been identified. Thus, a wide-open opportunity for research is the taxonomy and identity of bacteria and archaea; eukaryotic unicellular and microbial life, including fungi; nematodes, arthropods, and other invertebrate phylla. This knowledge will help advance understanding of how these organisms, and their communities, contribute to ecosystem services such as water filtration, storage, nutrient and $\mathrm{C}$ cycling, plant nutrition and drought resistance, plant diversity, and wildlife habitat. Also unresolved are the aboveground and belowground interactions between microbes, organic matter, decomposition, and nutrient cycles. Further, understanding epiphytes and canopy soils in temperate rainforests and their roles in nutrient accumulation and $\mathrm{C}$ storage is important (Box 10.1). Such emerging techniques as high-throughput 


\section{Box 10.1 Canopy Soils}

Old-growth temperate forests, per unit area, represent the longest living and largest stores of carbon on Earth (Urrutia-Jalabert et al. 2015). The old-growth temperate rainforests of the Pacific Northwest region have a large role in carbon emissions and sequestration because highimpact disturbance events are increasing soil respiration losses (Harmon et al. 2011), as well as the release of carbon stored in woody biomass (Luyssaert et al. 2008). These forests are known for their high gross primary productivity, high stores of carbon in soils, large numbers of fungal species, and propensity to host epiphytic and saprophytic species (Franklin et al. 1981; Tejo et al. 2014). Globally, they represent one of the most carbon-dense forest types (Keith et al. 2009), and they hold some of the region's highest biodiversity (Franklin et al. 2002). The resulting high structural variability, rainfall regimes, and associated diversity are conducive to the formation of a wide array of niches for biotic relationships (Frank et al. 2009). Despite this information, the role of abiotic and biotic interactions in the functioning of carbon and nutrient dynamics of these forests has rarely been described.

It is not widely known that these old-growth forest stands can accumulate significant amounts of canopy soil on tree branches (Van Pelt et al. 2006). Canopy or arboreal soils develop from the accumulation and decomposition of epiphytes and intercepted litter on branches and in bifurcated tree boles in both tropical and temperate rainforests (Haristoy et al. 2014; Nadkami 1981), and they contribute unique structural and functional components in these forests. In some stands, canopy soils were found to contribute as much as $20 \%$ and $25 \%$ to the nitrogen $(\mathrm{N})$ and carbon $(\mathrm{C})$ storage pools, respectively (Tejo et al. 2014). Riparian species (e.g., big leaf maple Acer macrophyllum Pursh.) can have canopy soils reaching depths $>35 \mathrm{~cm}$ (personal observation). Trees have adapted to the presence of these canopy soils as shown by the extensive growth of adventitious branch roots that are associating with symbiotic fungi (Nadkarni 1981) (e.g., Box Figs. 10.1 and 10.2). It is known that geomor-
Box Fig. 10.1 Adventitious roots in canopy soils of two old-growth big leaf maples in the University of WA study sites located in the Queets (a) and Hoh (b) Rivers in the Olympia Peninsula. WA. (Photo source: K Mafune)

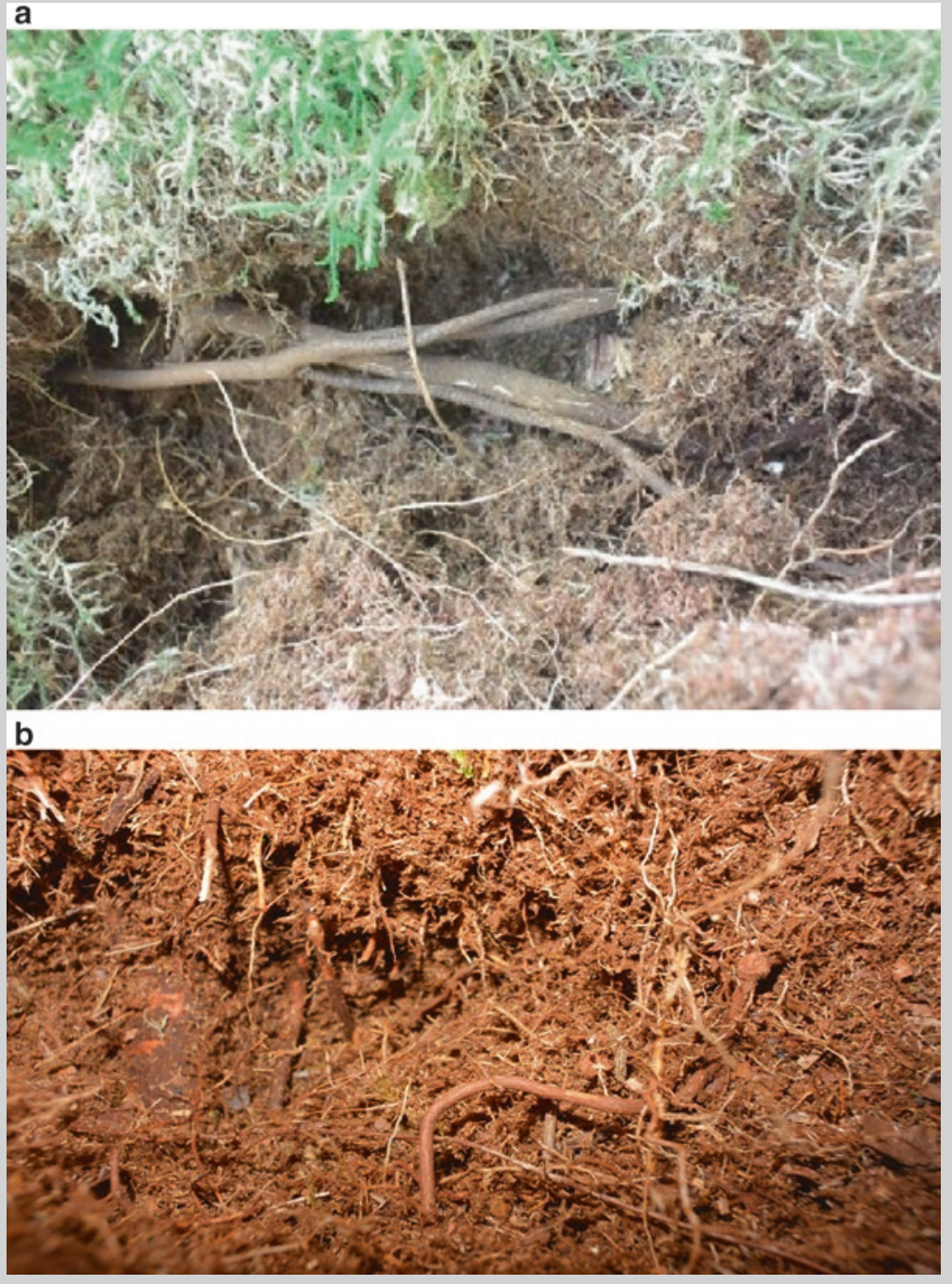


Box 10.1 (continued)

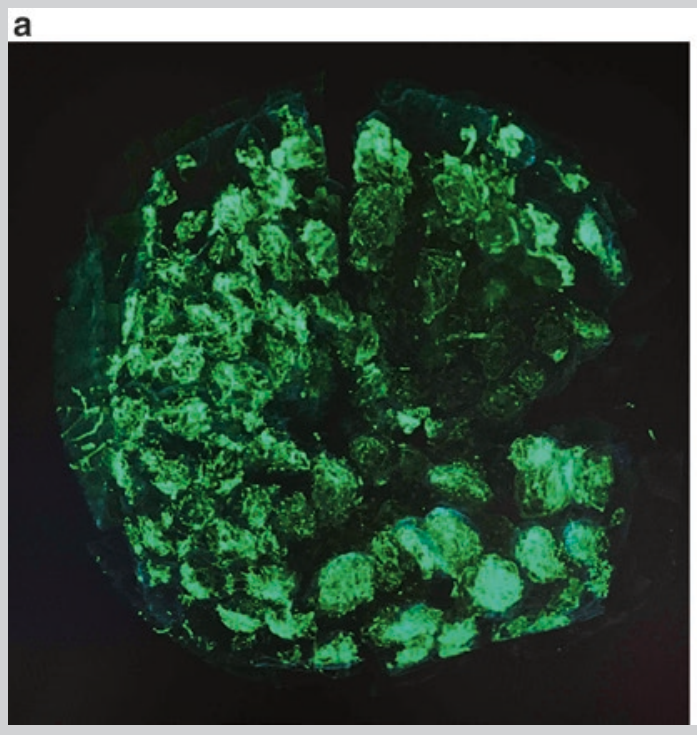

Box Fig. 10.2 (a) Confocal scan of an adventitious canopy-soil root cross-section with an extensive amount of intracellular coils, (b) lateral scan of intra- and intercellular hyphae within the cortical and

phology, hydrology, sediment, and riparian-derived large wood shape these riparian forests (Swanson and Lienkaemper 1982; Naiman et al. 2000; Abbe and Montgomery 2003). However, understanding the complexity of biotic and abiotic interactions in canopy soils is important to understanding the function of these forests, as they may strongly affect the characteristics of

\section{b}

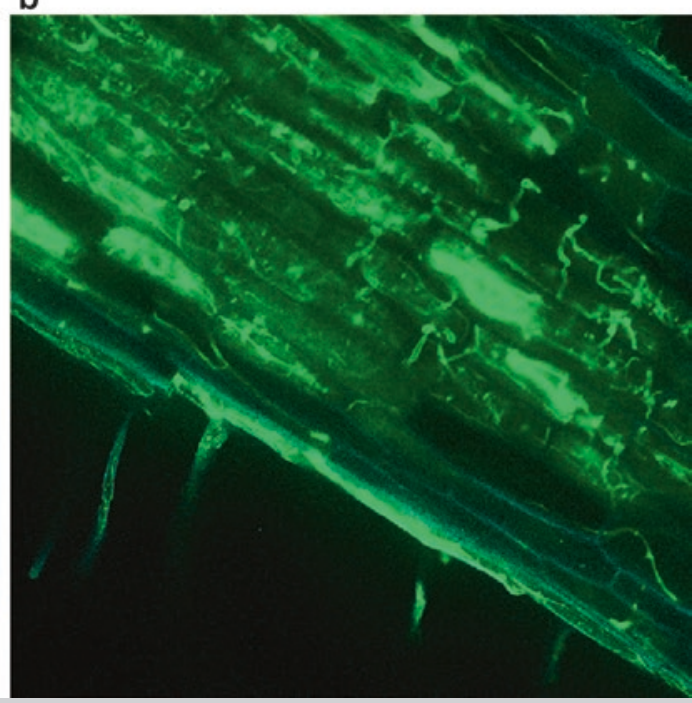

epidermal cell layers. The hyphae found in the epidermal cells also extend into the root-hairs. (Photo source: K Mafune)

organic matter and nutrient fluxes into streams, estuaries, and the atmosphere. In particular, studies of the canopy soil habitats are needed to understand how disturbances may impact greenhouse gas emissions and nutrient pools at the temporal and spatial scales of canopy soils in these productive and carbon-dense coastal temperate rainforests. sequencing and stable isotope probing can provide opportunities to deepen understanding of these effects.

- Understanding the unique properties and processes of hydric, wetland, and urban soils (Chaps. 6 and 7). While wetlands and urban areas make up a relatively small portion of the landscape, they provide highly valued ecosystem services that are largely mediated by soil processes, such as water purification and $\mathrm{C}$ sequestration (wetlands) and local food, shading, green landscapes, and biodiversity hotspots (urban areas). Key research challenges include understanding the soil processes of tidal freshwater wetlands, particularly $\mathrm{C}$ sequestration, and how those processes are mediated by tidal and terrestrial processes. For example, what are the watershed-scale dynamics for the transfer of organic matter nutrients and other chemicals through tidal freshwater wetlands and adjoining uplands and tidal waters? This information is important because tidal wetlands are at the interface of changing sea level and, particularly in the eastern United
States, are often within rapidly urbanizing regions. Additional basic research needs for urban soils include understanding processes of soil formation from humancreated parent materials (concrete, construction debris, landfill materials) and how to describe, quantify, and map the highly heterogeneous soils characteristic of urban areas.

\section{Understanding Disturbance and Stress Effects}

\section{Significance}

"Nature is always changing-there is no going back" (Chap. 8). Ecosystems are in a state of flux at many spatial and temporal scales, and soil formation, transformation, and loss are always occurring. Today, however, the pace, spatial scale, and magnitude of disturbances linked to human activ- 
ities are strikingly different. Disturbances can shift and diminish soil properties and processes such as long-term $\mathrm{C}$ storage, nutrient cycling, fertility, and productivity; species composition and diversity; and water infiltration, holding capacity, quality, and abundance and can increase erosion and sedimentation. Repetitive and highly intense disturbances can eliminate key functions, for example, turning peatlands from a net $\mathrm{C}$ sink to a net source, and can overwhelm or eliminate key services such as water purification. Understanding how disturbance affects soils is fundamental to the development of management practices that sustain and restore soils.

Disturbance agents identified repeatedly across the chapters, and regional summaries that can adversely affect the properties, functions, and productivity of soils include:

\section{Climate Change}

- Precipitation. Shifts in global precipitation patterns are producing more frequent and more intense rainfall and increased severity and frequency of both flooding and drought.

- Temperatures. Long-term increases in temperature variability, warming air temperatures along with increased solar radiation, and longer growing seasons will raise soil temperatures throughout the United States.

- Carbon dioxide $\left(\mathbf{C O}_{2}\right)$ concentrations. Atmospheric $\mathrm{CO}_{2}$ concentrations are increasing globally due to human activities, particularly the combustion of fossil fuels. This increase can indirectly impact soils through the effects of elevated $\mathrm{CO}_{2}$ on plant productivity. Small changes in soil $\mathrm{C}$ can also significantly increase or decrease atmospheric $\mathrm{CO}_{2}$ concentrations (Chap. 2 Introduction), resulting in mitigation or exacerbation of climate change.

\section{Fire}

- Wildfires are becoming more frequent, more intense, and larger in area as more than a century of fire suppression has increased fuel loads and warmer, drier climates have decreased fuel moisture for more extended periods (Abatzoglou and Williams 2016).

\section{Invasive Species, Pests, and Disease}

- Pests, pathogens, and invasions of weedy and non-native species (from microbial organisms to macrofauna and macroflora) are all sources of disturbance. Climate change is a significant driver favoring range extensions of some insects and pathogens (Bellard et al. 2018).

\section{Pollution}

- Water and air pollution and overuse of fertilizers and pesticides can cause accumulation, leaching, or volatilization of pollutants such as fertilizing $\mathrm{N}$, acidic compounds, mercury, organic pollutants, and toxic metals.

\section{Nonurban Land Uses}

- Nonurban soils are affected by land uses such as agriculture, forestry, grazing, road networks, energy development and mining, and recreational infrastructure and activities (Chap. 3).

\section{Urban Land Uses}

- Urban soils are disturbed directly by infrastructure development, construction, waste disposal, grading and stormwater management, sealing and paving, soil replacement and recycling, and lawn management and indirectly from urban climate, pollution, and non-native and invasive species (Chap. 7).

\section{Challenges and Opportunities}

- Understanding how to grow $\mathrm{C}$ pools and prevent or mitigate soil $\mathbf{C}$ loss. A key research need is understanding how $\mathrm{C}$ loss from organic soils can be minimized across organic tundra, boreal, agricultural, forest, and wetland soil types. An analysis of the most important and economically feasible mechanisms for storing $\mathrm{C}$ and their importance and potential by region would inform attempts to increase the pace and scale of $\mathrm{C}$ storage in soils nationally. Other key research needs include understanding how to minimize soil $\mathrm{C}$ loss from wildland fire and the potential value of biochar to sequester $\mathrm{C}$ and augment soil fertility and water holding capacity across soil types.

- Understanding how land use and management affect soil processes and properties. Many questions remain about how land use influences soils, especially in wetland ecosystems. Particularly important are systems sensitive to mercury methylation, nutrient loading, and burning. Large-scale manipulation experiments can be used to answer questions on the impacts of development and land use patterns on soils.

- Understanding the effects of climate shifts on soil properties and processes. Of specific interest are temperature, precipitation, and greenhouse gas effects on the stability of soil $\mathrm{C}$, moisture, nutrients, and biota and the ecological functions provided by them. Research is needed that can help forest and rangeland managers anticipate climate change and protect or enhance soils to promote ecosystem resistance and resilience. Some areas where improved understanding and research are needed are included below.

- Understanding how precipitation shifts affect soil water storage, water availability for the growing season, erosion, sedimentation, and water quality. Reduced snowpack in particular may severely limit water storage and availability during the growing season for much of the western United States. In contrast, 
increasing rainfall amounts and intensities are expected to increase runoff and erosion of agricultural soils by about $2.0 \%$ and $1.7 \%$, respectively, for each $1 \%$ rise in mean annual precipitation (Nearing et al. 2004). What is the prognosis for forest and rangeland soils and what steps can be taken to mitigate projected effects?

- Understanding how temperature shifts affect soil microbial activity, decomposition rates of soil organic matter, and nutrient loss. Higher temperatures tend to increase decomposition and soil respiration rates, but how significant is the effect, and what are the quantities of $\mathrm{CO}_{2}$ released to the atmosphere require further research.

- Understanding how invasive organisms affect the composition, relationships, and roles of soil biota. Key research challenges include developing indicators to identify priority conservation areas (given that plant and soil biodiversity is not well correlated in forests or rangelands) and characterizing late-seral soil biology to inform restoration of desired or late-seral plant communities. Systematic monitoring can answer key research questions, such as: What invasive soil organisms are present and how much have they spread? How do plant, animal, insect, and pathogen invasive species impact soil $\mathrm{C}$, and how can managers change practices to alter invasive species effects on ecosystem services?

- Wetlands-biggest bang for the buck? Though wetlands make up a relatively small portion of the terrestrial landscape, they provide highly valued ecosystem services that are largely mediated by soil processes, including water purification and $\mathrm{C}$ sequestration. Research that provides information to improve wetland restoration practices can have a relatively substantial return for the investment.

- Using urban soils to study disturbance effects. Humancreated parent materials and effects of urban land use changes can be thought of as a "natural experiment" in soil-forming processes. There is no typical urban soil, and soil horizon development often occurs more rapidly in urban compared to young nonurban soils (Pouyat et al. 2009). Moreover, many urban environmental effects include local climatic shifts. Thus, urban soils may be used to study the multifactorial effects of climate change on forest and grassland remnants situated in urban landscapes.

- Understanding how soil pollution affects soil properties and biota. Use and integrate research in soil chemistry modeling, soil mapping, atmospheric deposition and critical loads, and measurements of surface water quality and soil chemistry to better predict soil pollution effects and the ability of soil to recover from these effects. Evaluate spatial extent and risks from soil pollution in forests, grasslands, wetlands, and urban soils.
- Understanding how increased fire frequency and severity affect soil properties and biota. Of particular concern are effects on (1) permeability to water, erosion and sedimentation rates, and water quality; (2) amount of soil organic matter lost to combustion and releases of sequestered $\mathrm{C}$; and (3) alterations in mineralogy and chemistry of soils that affect soil biota and availability of plant nutrients. Within these effects, there are questions related to spatial extent of effects, recovery times, and factors that promote resistance and resilience of soils. For example, wildfire increases are projected to double the rates of sedimentation in one-third of 471 large watersheds in the western United States by about 2040 (Neary et al. 2005). Understanding sedimentation effects on stream channel characteristics and water quality can inform management of extreme flows.

\section{Monitoring, Modeling, Mapping, and Data- Sharing: A Key Component of Knowledge Acquisition and Decision-Making for Land Managers}

\section{Significance}

The right level of investment of resources in monitoring, assessments, and technological development can provide for current and future information needs (Chap. 9). Collection of adequate data to answer pressing and management-centered questions and meet information needs is critical for longterm sustainability in the forest and rangeland sectors.

\section{Challenges and Opportunities}

- Planning strategically. Strategic planning is needed to review and prioritize existing networks, incorporate new technologies and datasets, and grow and connect new research partnerships.

- Promoting interdisciplinary teams with access to a range of information. Data sources range from monitoring networks to field and laboratory experiments, the utilization of genetic and chemical data, light detection and ranging (LiDAR), digitized photographic imagery, and satellite data. An example opportunity for soil, biological, and physical scientists is the study is useful of long-term effects of higher temperatures and $\mathrm{CO}_{2}$ enrichment on forest and rangeland soils and how to model and manage soil responses. Formation interdisciplinary teams to use long-term forest research sites is useful to develop and test conceptual models and new instrumentation, all of which could improve quantification of weathering and nutrient cycling processes. 
- Sustaining key monitoring networks; collection, storage, and provision of soil network data; and associated support staff.

- The United States is a world leader in long-term field studies with large multiagency, multigenerational networks of research sites. Continuous monitoring is a key component of science-based management and restoration. Sustaining and augmenting these networks and providing new opportunities to integrate knowledge across programs will increase benefits from the long-term investment.

- Examples of key networks include the USDA Forest Service's Forest Inventory and Analysis program's soil indicator, Long-Term Ecological Research sites, LongTerm Soil Productivity network, Critical Zone Observatories, and the National Environmental Observatory Network. See also Appendix B.

- Supporting improvements in metadata, coverage, standardization, and collation of independent datasets to facilitate data access and interpretation. Support strategic planning to make sure the networks and systems are obtaining the information that will be needed in the future.

- Strategic integration of existing programs and datasharing can counter the need for additional funding, although additional sources of stable support for longterm research sites would enhance the pace of research. Explore new public-private partnerships.

- Conducting long-term experimental studies. Some questions can be answered with short-term studies, but long-term studies (longer than a rotation) of forest management effects help managers understand trends and anticipate longer-term impacts of decisions on soil properties. Initial and subsequent monitoring provides data to guide adaptive management in areas impacted by drought, wildfire, overgrazing, climate change, and insect and disease outbreaks.

- Continuing the legacy of twentieth-century paired catchment studies. Research depends on data from these and other networks to explain underlying soil hydrologic processes that can be used to develop management approaches to reduce erosion and sedimentation, mitigate pollution, and optimize infiltration.

- Increasing the number of sites with less-intensive monitoring to improve statistical power to extrapolate across landscapes. It is important to maintain or develop less-intensive monitoring of soil conditions across many sites, because the number of intensive sites does not provide the statistical power needed to extrapolate to actual forest and rangeland soils across landscapes, which is particularly true for measurements lacking in forest and rangeland soils such as soil moisture content. Systematic approaches to soil resampling programs across gradients of natural and human-impacted landscapes can enhance effective environmental monitoring and assessment (Lawrence et al. 2013).

- Integrating data collected by terrestrial field monitoring installations with digitized aerial and remote sensing data to provide near real-time assessment of change in soil and vegetation properties. New aerial, satellite, and space technologies are providing ever more detailed, spatially explicit, and temporally explicit information about the planet's soil, water, and air resources. Explore uses of remotely collected soil temperature, soil moisture content, and gas concentration data to answer questions about soil responses and vegetation patterns to ongoing change at multiple scales.

- Building and supporting data clearinghouses with consistent metadata for collaborative sharing across agencies and organizations and to assist research and management.

- Continuing development of sound methods for monitoring, assessing, and managing ecological integrity by improving our understanding of fluxes and processes and developing models to integrate monitoring and process-level studies. It is critical to make this data and information available for managers and policy makers in an easy-to-use form to promote the maintenance of ecosystem services and inform policies to recover degraded soils and promote healthy soils.

- Continuing development of more uniform, multi-scale soil mapping products for the United States to aid research and management efforts. Continue to invest in hierarchically nested, multiresolution soil mapping systems and integrated soil and vegetation ecological mapping products.

- Using new molecular technologies to characterize the biological diversity of soils and the effects of climateinduced change on biodiversity. Expanding molecular technologies offers unprecedented possibilities for addressing ecological questions about biological diversity. Improved understanding of soil biodiversity composition, function, and resilience will assist development of best management and adaptive management practices.

- Using the latest statistical and modeling techniques to (1) understand shifts in soil-dependent biological communities under natural conditions and under disturbance regimes and (2) identify methods to mitigate soil pollution, control target invasive species, and increase the resilience of soils to climate change. 


\section{Training the Next Generation of Scientists}

\section{Significance}

The skills and abilities of the next generation of soil scientists will be needed to meet the research challenges of the present and future. Yet academic departments; Federal, state, and private-sector jobs; and industries that have focused on soil science are shrinking. Fewer young scientists are being trained in the taxonomy of biological organisms, and the field is at risk of losing knowledge and capacity as older scientists retire.

\section{Challenges and Opportunities}

- Creating broad, inclusive opportunities for educating students and the public at large about science, technology, engineering, and mathematics (STEM) subjects, including citizen-science education opportunities involving soils. Developing programs with urban, rural, and regional relevance is also useful.

- Encouraging young scientists to pursue the taxonomy of soil biota. Describing species-particularly microbes and invertebrates-offers a special opportunity to young scientists looking for an uncrowded field where they can make a difference.

- Channeling support to successful departments and positions and use advances in technologies to enhance networking opportunities among sites, scientists, and agencies. The goal is to form a more cohesive national interorganizational task force on understanding forest and rangeland nutrient pools and cycles.

\section{Managing Soils in an Age of Accelerated Disturbance, Land Use, and Environmental Changes}

\section{Significance}

Sharing of research information with managers has improved forest and rangeland soil management practices significantly over the past 40 years. Limiting loss of soil productivity has been the focus of soil management on national forest lands since the passage of the National Forest Management Act of 1976. Current Forest Service directives (USDA FS 2012) rely on science-based recommendations to guide planning, environmental assessments, and execution of management activities related to national forest and grassland soils. Due to the increasing pace and scale of disturbances, land management decisions on all lands (public and private) rely more than ever on up-to-date science to sustain soil health and productivity (Chap. 8).

\section{Challenges and Opportunities}

- Planning strategically. Develop strategies to help overcome past, contemporary, and future stressors. Practice proactive maintenance to avoid more expensive soil remediation later.

- Linking efforts of researchers, managers, policymakers, communities, nongovernmental organizations, and private enterprise to meet common goals. Actions might include explore roles that communities, local governments, private enterprise, and nongovernmental organizations can play and how those entities can be integrated into existing networks, data-sharing, and decision-making at management and policymaking levels.

- Providing opportunities for scientists and managers to develop and test innovative ideas, and share that information with land managers in a timely manner to support continued advances in management and restoration approaches.

- Testing pre-fire treatments to improve resilience of forest soils to wildfire. Massive efforts are underway to restore watersheds by removing accumulated biomass through mechanical means, slash burning, and prescribed burning. Some questions worth exploring in this arena might be: What happens when fire passes through treated stands relative to untreated stands? How do different restoration prescriptions protect the physical, chemical, and biotic components of the soils? Which soils and localities benefit most from restoration activities and are most easily made resilient to fire? How do legacy disturbances affect response to treatments?

- Developing applications of biochar soil amendments in the larger context of hazardous fuel reduction. Pilot studies to develop and compare technologies for, and to assess the costs and benefits of (1) converting biomass generated by forest restoration and hazardous fuel treatments to biochar, (2) utilizing biochar to sequester $\mathrm{C}$ and improve fertility and water-holding capacity of soils, and (3) reducing air pollutants associated with hazardous fuel reduction.

- Monitoring recovery from disturbance and pollution, and apply understanding of regional and local soil differences to evaluate and mitigate risk. Some actions might include: standardizing and appropriately scaling monitoring data to meet planning and management needs within the context of ecosystem services and habitat fragmentation. Also useful would be to conduct initial and subsequent postdisturbance monitoring or risk assess- 
ments (or both) to guide adaptive management, land management planning, pollution mitigation, silvicultural prescriptions, and other practices that affect soil health and productivity.

- Developing multifactor, threshold-based best management practices (BMPs). Some options might be integrating knowledge of the physical, biological, and chemical attributes of managed soils into BMPs. Identifying thresholds for soil function and structure, or "vital" signs of soil health are important as well. Including guidance on how to select appropriate tools and preparing comprehensive synthesis reports and distilled fact sheets to complement BMPs are also useful.

- Managing soil organic matter, $C$, nutrients, and water. Some ways forward might be to develop and implement BMPs to (1) increase $\mathrm{C}$ storage in all land use types, partially mitigate soil $\mathrm{C}$ degradation, and promote rebuilding of soil organic carbon (SOC) postdisturbance; (2) promote retention and growth of native vegetation (fuel management, reforestation, and invasive weed control); and (3) leave or add organic residues on-site. Improve assessments of SOC vulnerability to disturbance by considering factors related to quantity and quality of organic matter inputs and soil microbial accessibility and activity.

- Managing soils for biotic health and diversity. To address these parameters developing BMPs to optimize soil biotic communities under management regimes such as thinning, prescribed fire, and grazing could be important. Other considerations might be to promote biodiversity by minimizing management activities that cause the greatest level of disturbance (e.g., severe soil heating or exposure of bare mineral soils), using knowledge of soil resilience to different types of impacts. Conducting cost versus benefit analyses to inform management options would be very useful here.

- Managing soils to promote public health and food security in urban areas. Implementing research and technologies for growing food in urban areas, designing green corridors and parks, and utilizing vegetation for shading and cooling would be useful considerations. These actions can improve food sufficiency and quality and lower the cost of food; improve livability; and reduce costs for cooling, respectively. Preparing management guidelines that conserve water, conserve soil microbiota, prevent soil erosion, prevent or mitigate soil contamination, expand soils and gardens in urban areas, and reduce the $\mathrm{C}$ cost related to soil organic matter loss and greenhouse gas emissions of growing food, would be useful as well.

- Restoring and managing wetland and hydric soils. Use comprehensive assessment of site and environmental conditions as the foundation for BMPs to ensure the long-term viability and functionality of natural wetlands, hydric soils, and restored wetlands.

\section{Conclusions}

Soils provide key ecosystem services essential to the health and welfare of humans. Accelerated disturbances, changes in land use and the environment, and continued population growth are increasing pressure on forest, rangeland, wetland, and urban soils to provide sufficient water, food, and fiber and continue to moderate climate change. Sustaining the health, biodiversity, and productivity of these soils into the future is imperative for sustaining the ecosystem services that soils provide. By addressing relevant research questions in relation to soil properties, functions, environmental stress, and disturbance effects, soil science can inform successful policies and practices. This research will be aided by the opportunities provided by new technologies, existing monitoring networks, and advances in mapping and data accessibility and new models to integrate monitoring and process-level studies. Training the next generation of scientists, improving opportunities for interdisciplinary collaboration among scientists and managers, and supporting programs to improve soil health and benefits to both urban and rural communities will help to ensure continued national strength in soils research and applications of its findings.

\section{Literature Cited}

Abatzoglou JT, Williams AP (2016) Impact of anthropogenic climate change on wildfire across western US forests. Proc Natl Acad Sci 113(42):11770-11775

Abbe TB, Montgomery DR (2003) Patterns and process of wood debris accumulation in the Queets River basin. Wash Geomorphol 51:81-107

Bellard C, Jeschke JM, Leroy B, Mace GM (2018) Insights from modeling studies on how climate change affects invasive alien species geography. Ecol Evol 8(11):5688-5700

Decaëns T, Jiménez JJ, Gioia C et al (2006) The values of soil animals for conservation biology. Eur J Soil Biol 42:S23-S38

Frank D, Finchkh M, Wirth C (2009) Impacts of land-use on habitat functions of old-growth forests and their biodiversity. In: Wirth C, Gleixner G, Heimann M (eds) Old-growth forests: function, fate and value. Springer, Dordrecht, pp 429-450

Franklin JF, Cromack K Jr, Denison W et al (1981) Ecological characteristics of old-growth Douglas-fir forests, General Technical Report PNW-GTR-118. U.S. Department of Agriculture, Forest Service, Pacific Northwest Forest and Range Experiment Station, Portland, $48 \mathrm{p}$

Franklin JF, Spies TA, Van Pelt R et al (2002) Disturbances and structural development of natural forest ecosystems with silvicultural implications, using Douglas-fir forests as an example. For Ecol Manag 155:399-423

Haristoy CT, Zabowski D, Nadkarni N (2014) Canopy soils of sitka spruce and bigleaf maple in the Queets River Watershed, Washington. Soil Science Society of America Journal 78(S1):S118-S124 
Harmon ME, Bond-Lamberty B, Tang J, Vargas R (2011) Heterotrophic respiration in disturbed forests: a review with examples from North America. J Geophys Res 116:G00K04. https://doi. org/10.1029/2010JG001495

Jackson RB, Lajtha K, Crow SE et al (2017) The ecology of soil carbon: pools, vulnerabilities, and biotic and abiotic controls. Annu Rev Ecol Evol Syst 48(1):419-445

Keith H, Mackey BG, Lindenmayer DB (2009) Re-evaluation of forest biomass carbon stocks and lessons from the world's most carbon-dense forests. Proc Natl Acad Sci 106(28):11635-11640

Lawrence GB, Fernandez IJ, Richter DD et al (2013) Measuring environmental change in forest ecosystems by repeated soil sampling: a North American perspective. J Environ Qual 42(3):623-639

Luyssaert S, Schultze E-D, Borner A et al (2008) Old growth forests as global carbon sinks. Nature 455:213-215

Nadkarni NM (1981) Canopy roots: convergent evolution in rainforest nutrient cycles. Science 214:1023-1024

Naiman RJ, Bilby RE, Bisson PA (2000) Riparian ecology and management in the Pacific Coastal Rain Forest. Bioscience 50:996-1011

National Forest Management Act of 1976; Act of October 22, 1976; 16 U.S.C. 1600

Nearing MA, Pruski FF, O’Neal MR (2004) Expected climate change impacts on soil erosion rates: a review. J Soil Water Conserv 59(1):43-50

Neary DG, Ryan KC, DeBano LF, (eds) 2005 (revised 2008) Fire effects on soil and water. General Technical Report RMRS-GTR- 42-vol.4. U.S. Department of Agriculture, Forest Service, Rocky Mountain Research Station, Ogden, $250 \mathrm{p}$

Pouyat R, Carreiro MM, Groffman PM, Pavao-Zuckerman M (2009) Investigative approaches to urban biogeochemical cycles: New York metropolitan area and Baltimore as case studies. In: McDonnell MJ, Hahs AK, Breuste JH (eds) Ecology of cities and towns: a comparative approach. Cambridge University Press, Cambridge/Oxford, pp 329-354

Swanson FJ, Lienkaemper GW (1982) Interactions among fluvial processes, forest vegetation, and aquatic ecosystems, south fork Hoh River, Olympic National Park. In: Franklin JF, Starkey EE, Matthews JW (eds) Ecological research in National Parks of the Pacific northwest. Oregon State University, Forest Research Laboratory, Corvallis, pp 30-34

Tejo CF, Zabowski D, Nadkami NM (2014) Canopy soils of Sitka spruce and bigleaf maple in the Queets River watershed, Washington. Soil Sci Soc Am J 78(1):118-124

Urrutia-Jalabert R, Malhi Y, Lara A (2015) The oldest, slowest rainforests in the world? Massive biomass and slow carbon dynamics of Fitzroya cupressoides temperate forests in southern Chile. PLoS One 10(9):e0137569. https://doi.org/10.1371/journal.pone.0137569

USDA Forest Service [USDA FS] (2012) National Forest System Land Management Planning. 36 CFR Part 219 RIN 0596-AD2. Fed Regis Rules and Regul 77(68):21162-21276

Van Pelt R, O’Keefe TC, Latterell JJ, Naiman RJ (2006) Riparian forest stand development along the Queets River in Olympic National Park, Washington. Ecol Monogr 76:277-298

Open Access This chapter is licensed under the terms of the Creative Commons Attribution 4.0 International License (http://creativecommons. org/licenses/by/4.0/), which permits use, sharing, adaptation, distribution and reproduction in any medium or format, as long as you give appropriate credit to the original author(s) and the source, provide a link to the Creative Commons license and indicate if changes were made.

The images or other third party material in this chapter are included in the chapter's Creative Commons license, unless indicated otherwise in a credit line to the material. If material is not included in the chapter's Creative Commons license and your intended use is not permitted by statutory regulation or exceeds the permitted use, you will need to obtain permission directly from the copyright holder. 